\title{
The Financial Accounting Standards Board's Fair Value Mandate: Are Level 3 Assets and Liabilities Being Measured Accurately?
}

\author{
Robert J. Cochran ${ }^{1}$ \\ ${ }^{1}$ College of Business and Economics, Longwood University, Farmville, VA 23909, USA \\ Correspondence: Robert J. Cochran, College of Business and Economics, Longwood University, 201 High Street, \\ Farmville, Virginia 23909, USA
}

Received: December 5, 2017

Accepted: January 11, 2018

Online Published: January 15, 2018

doi:10.5430/afr.v7n2p33

URL: https://doi.org/10.5430/afr.v7n2p33

\begin{abstract}
This study asks the following question with respect to level 3 fair value assets and liabilities: are level 3 fair value assets and liabilities being measured accurately? An argument is made that since level 3 markets do not exist (as defined in ASC 820), it is not possible to determine a level 3 value. Data is examined, both pre- and post- SFAS No. 157 with respect to a specific level 3 asset that can be found on the balance sheet of most publically traded financial institutions, mortgage loan servicing rights. The data suggests that the FASB's attempt to clarify fair value had no effect on the levels of capitalization of mortgage loan servicing rights. An additional argument is made that the language in ASC 820 undermines the requirement that level 3 fair values reflect a "market" value rather than an "investment" value.
\end{abstract}

Keywords: SFAS No. 157, ASC 820, Fair value, Level 3 assets, Mortgage loan servicing rights, MSRs

\section{Introduction}

This study asks the question with respect to level 3 fair value assets and liabilities: are level 3 fair value assets and liabilities being measured accurately? The answer to this question is important due to the materiality of level 3 assets and liabilities on published financial statements. If the answer is "no," the implications for the Financial Accounting Standards Board (FASB) and SFAS No. 157 - "Fair Value Measurements" (currently ASC 820 - "Fair Value Measurements") are dire.

The FASB concluded long ago that fair value was the appropriate measurement principle for selected assets and liabilities. With respect to these assets and liabilities, fair value was deemed to provide a more relevant measure of their value. Prior to the issuance of SFAS No. 157 in 2006, the measurement principle was applied piecemeal as the FASB addressed specific assets and liabilities in individual standards. In these standards, the FASB did not specifically define fair value. Financial statement issuers interpreted fair value differently. Was it a value in place, replacement value, market value, etc.? Could it differ for like assets and liabilities among firms? With the issuance of SFAS No. 157, the FASB attempted to answer these questions and impose a consistency of application among all issuers.

What follows is a review of the fair value hierarchy, as well as an explanation of mortgage loan servicing rights (MSRs) since they are the topic of this paper. Prior research is examined that suggests the propensity of managers to exercise discretion in accounting choice when given the opportunity. This is important to this paper since the measurement of level 3 assets and liabilities is more subjective than the measurement of level 1 and 2 assets and liabilities Prior research is also reviewed which examines the value relevance of level 3 fair value measurements (e.g., the stock market's reaction to fair value measures). These papers do not specifically answer the question being asked in this paper. A suggestion as to the research method that could be used to answer the questions posed is offered. Only two such papers are found that utilize that research method. While the purpose of those papers was not to answer the questions asked in this paper, the data and results from those papers is examined here to suggest answers to the question in this paper.

\subsection{The Fair Value Hierarchy}

With the issuance of SFAS No. 157, the FASB clearly established the notion that fair value is a market-driven concept and firmly rejected the notion that fair value is an economic value or a value-in-place value. The unequivocal definition of fair value from SFAS No. 157 is, “. . . the price that would be received to sell an asset or 
paid to transfer a liability in an orderly transaction between market participants at the measurement date." In addition to defining fair value, the standard segregated assets and liabilities for which fair value is the mandated measurement principle into three categories:

- level 1 assets and liabilities for which there exist active and liquid markets on which the assets and liabilities are traded and there exist observable market quotes which can be used to determine fair value;

- level 2 assets and liabilities for which there do not exist active and liquid markets on which the assets and liabilities are traded and therefore no observable market quotes, but are sufficiently similar to a level 1 asset or liability for which an observable quote, appropriately adjusted, may be used to determine fair value; and

- level 3 assets and liabilities for which there do not exist active and liquid markets on which the assets and liabilities are traded and therefore no observable market quotes, and are sufficiently dis-similar to a level 1 or level 2 asset or liability such that there is no observable input (appropriately adjusted or otherwise) which may be used to determine fair value.

The reliability of the determined fair value declines as assets and liabilities move from level 1 to level 3. Level 1 and level 2 fair value determinations are the most reliable since no assumptions about market participant assumptions need be made. These values are predicated on observable inputs as markets exist that provide a reliable consensus of the assumptions that market participants are making.

Level 3 values are not predicated on observable inputs about market participants' assumptions since, by definition, no market exists to consolidate market participants' assumptions. This creates a bit of a Catch-22. Level 3 values are to be determined using the market's assumptions where no market exists. Since no market exists, a market-based value cannot be achieved. Hence, ASC 820 directs firms to use the "best information available" and concedes that that may be the firm's own assumptions. If using their own assumptions, the firm should endeavor to adjust their assumptions if they know them to be overly conservative or aggressive. Firms are not required to "undertake exhaustive efforts" when adjusting their assumptions. Regardless of how a firm measures fair value, the measurement objective remains the same, an exit price from the perspective of the market. However, if a firm were to use their own assumptions with little, if any, adjustments (not exercising exhaustive efforts), the result would be firm-specific values, not market values, exactly opposite of what the FASB mandated. Is it reasonable to assume that firms would do just that?

\subsection{Mortgage Loan Servicing Rights}

MSRs are an asset that can be found on the balance sheet of most publicly traded financial services companies. MSRs represent the current value of the right to collect, account for and remit to the owner of the loan the principal and interest portions of the payment. This service is provided to the owner of a loan for a fee (usually calculated as a percentage of the outstanding principal balance of the loan). Across firms, the amount of MSRs is significant. The 2016 year-end annual report for JPMorgan Chase \& Co. alone reports MSRs in excess of $\$ 6.1$ billion on a servicing portfolio of $\$ 593.3$ billion, or 111 basis points (BP). The balance represents $2 \%$ of total stockholders' equity. Over the course of thirty-five years, since the issuance of SFAS No, 65 - "Accounting for Certain Mortgage Banking Activities," the accounting for MSRs has evolved dramatically. While the value to be recorded was always understood to be fair value, the definition of fair value was not consistent across firms. The accounting for MSRs was finally addressed with the issuance of SFAS No. 156 - "Accounting for Servicing of Financial Assets - An Amendment of FASB Statement No. 140" and subsequently, SFAS No. 157.

Under the guidance of SFAS No. 65, the only MSRs that were recognized on the balance sheet were those that were acquired through a purchase transaction. MSRs that were the result of a financial institution's own mortgage loan origination efforts were not allowed to be capitalized. As a result, servicers sought to sell their originated portfolios that were not capitalized and then immediately purchase a similar portfolio, the purchase price of which could be capitalized. This method around the prohibition of capitalizing one's own originated portfolio was costly and time consuming and confusing to borrowers who would be directed to remit their monthly payments to the new servicer immediately after origination. Frequently, the set-up of the servicing on the new servicer's system would not be complete prior to the time borrowers were required to remit their payments to the new servicer. It was a costly, cumbersome and inefficient environment.

In 1995, the FASB issued SFAS No. 122 - "Accounting for Mortgage Servicing Rights, an amendment of FASB Statement No. 65" which allowed for the capitalization of a servicer's originated servicing rights at the time the loan and the servicing were split and the loan sold to an investor. SFAS No. 122 eliminated the need to sell the rights created by an institution's own originations followed by the immediate purchase of a similar portfolio of rights. 
While the measurement principle in SFAS No. 122 was referred to as "fair value" no specific definition was provided. The value was calculated as the present value of the net servicing fees to be earned over the life of the loans using some form of discounted present value (DPV) model or option-adjusted spread (OAS) model. The fair value was considered to be an investment value or asset-in-place value. This meant that an individual portfolio could have a different value in the hands of one servicer than the same portfolio would have in the hands of a different servicer. The different values would be due to differences among servicers with respect to firm characteristics that affect the value of the servicing. Some firms enjoy economies of scale, are more efficient servicers, have a better hedging strategy, etc., hence, the portfolio has a higher value for them than the same portfolio would have in the hands of a servicer that does not enjoy economies of scale, is less efficient or has little or no hedging strategy, etc. These, and many other differences, resulted in similar portfolios being recorded at significantly different values. These differences, so long as they resulted from firm-specific servicing related characteristics, were acceptable per the extant accounting literature at the time. What was not permissible were differences in value resulting from firm-specific characteristics that are not servicing related. With the issuance of SFAS No. 157 differences resulting from differing firm-specific servicing related characteristics is no longer allowed. All firms should measure the value of a portfolio as the value the market would pay to acquire the portfolio in a sales transaction. That value is the same for all firms for a given portfolio.

\subsection{Prior Research}

\subsubsection{Positive Accounting Theory and Opportunistic Behavior}

The accounting literature is replete with studies that support the notion that when given the opportunity to exercise discretion, managers will do so to their advantage. Positive Accounting Theory (PAT), first introduced by Watts \& Zimmerman in 1978, suggests that when given a choice among accounting alternatives, managers will make choices in their own self-interest. PAT posits that three firm characteristics (size, debt-to-equity ratio, and use of incentive compensation) will influence managers in specific directions (income increasing vs. income decreasing). PAT suggests that larger firms will chose income decreasing accounting alternatives to avoid unwanted regulatory scrutiny, firms with high debt-to-equity ratios will chose income increasing accounting alternatives to avoid triggering debt covenants and firms that utilize incentive compensation will chose income increasing accounting alternatives to maximize incentive compensation. PAT has been tested extensively and is almost always supported. Other prior research suggests that firms may be more likely to exercise discretion with respect to choices that are less visible to the users of the financial statements. Alali and Anandarajan (2015) found that in the presence of level 3 fair value assets, managers of large banks were less likely to use the loan loss provision for earnings management. The suggestion is that earnings management using level 3 assets and liabilities is less obvious than other earnings management opportunities. Mannan, Menini \& Parbonetti (2015) examined analysts' forecasts with respect to fair value assets and liabilities. They concluded that, “. . . analysts' perceive that managers convey useful information through level 2 figures but act opportunistically in measuring level 3 fair value figures."

\subsubsection{Value Relevance of Fair Value Measures}

A review of the literature published since the issuance of SFAS No. 157 finds numerous papers that examine the value relevance of fair value measures. These papers examine the relationship between fair value measures and stock prices. The research examines how the stock market views the fair values being reported by measuring the impact of certain fair value measurements on firms' stock price. The research supports the notion that the stock market places less value on fair value measurements as they progress though the fair value hierarchy. Examples include Song \& Thomas (2010) and Tan (2015) that concluded that level 3 values were less value relevant than level 1 and level 2 values. However, less relevant does not necessarily mean less accurate. These papers beg the question as to whether the fair value measures being reported are, in fact, fair value. The results of the studies that examine value relevance would appear to indicate that the market may not think they are, at least with respect to level 3 values. Almost non-existent is empirical research that asks the question, "Are the fair value measures being reported an accurate measure of fair value?"

\section{Method (A Comparison of Two Cross-sectional Studies)}

To answer the question posed in the introduction to this paper, studies need to be conducted that examine individually specific level 3 assets and liabilities across firms. If fair value is being accurately measured, one would expect such studies to find value distributions across firms to be clustered around the mean with a small standard deviation. Only two such studies have been found. Both examined the same level 3 fair value asset, MSRs. The first study published in Research in Accounting Regulation (Cochran, Coffman \& Harless, 2004) examined the capitalization of MSRs for the period 1996 - 2000. The second study published in Accounting and Finance Research 
(Cochran \& Shelnutt, 2014) examined the capitalization of MSRs for the period 2007 - 2010. The two studies used the same research design but came to different conclusions.

Both of these studies were conducted to determine whether managers of financial institutions with MSRs were exercising discretion when recording the value of MSRs as predicted by PAT. The research method used by both studies is identical. The 2004 study covered a time period (1996 - 2000, pre-SFAS No.157 and pre-financial crisis) when MSRs were not well-known or understood and scant attention was being given the asset by regulators or the public. The results were supportive of PAT in that managers did exercise discretion. The 2014 study covered a time period (2007 - 2010, post-SFAS No.157 and post-financial crisis) when mortgage companies were the subject of significant governmental and public scrutiny. The results were not supportive of PAT. The authors of the 2014 study offer a detailed discussion as to why the results were not supportive. As an example, executive compensation was being scrutinized and criticized by regulators immediately subsequent to the financial crisis. As such, incentive compensation was not as high in the post-financial crisis period as in the past. At the same time firms were experiencing unexpected losses and were seeking ways to mitigate those losses. Increasing the capitalization (fair value) of MSRs would accomplish this goal. While the results of the 2014 study did not support PAT the results do not eliminate the real possibility that managers used the MSRs to mitigate the extensive losses being experienced after the financial crisis. As Alali and Anandarajan (2015) and Mannan, Menini \& Parbonetti (2015) suggest, in the presence of level 3 assets and liabilities, managers may use them as a less transparent way to manage earnings.

The motivation for the 2014 study was to determine whether the subprime mortgage market crisis moderated the level of discretion exercised by managers with respect to MSRs, not to determine whether the issuance of SFAS No. 157 moderated the level of discretion exercised by managers with respect to MSRs. Nonetheless, that the two studies are pre- and post- subprime mortgage crisis as well as pre- and post- SFAS No. 157 offers an opportunity to draw conclusions regarding the effects of SFAS No. 157.

Because the 2004 study was conducted prior to SFAS No. 157 when fair value was considered to be a firm-specific value, firm specific characteristics with respect to their servicing strengths and weaknesses could very well give rise to a wide range of values across firms. The 2014 study examined the same asset for a period post-SFAS No. 157 when differences in firm characteristics with respect to their servicing strengths and weaknesses should not be considered. Because the 2004 study supported PAT, the conclusion that managers exercised discretion could not be rejected. Even though the 2014 study did not support PAT, it simply means that the three characteristics identified by PAT were not influencing the value of MSRs, but does not answer whether other firm-specific characteristics were influencing the level of capitalization.

A comparison of the two studies does reveal a disturbing finding. The authors found that the distribution (range, mean and standard deviation) of the two populations are the same (reject the null hypothesis of unequal mean, $\mathrm{p}=0.5002)$.

Table 1. Descriptive statistics

\begin{tabular}{lllll}
\hline & Mean & $\begin{array}{l}\text { Standard } \\
\text { Deviation }\end{array}$ & Minimum & Maximum \\
\hline 2004 Study & $78.95 \mathrm{BP}$ & $50.94 \mathrm{BP}$ & $0.00 \mathrm{BP}$ & $379.91 \mathrm{BP}$ \\
& & $-1.55 \mathrm{SD}$ & $+5.91 \mathrm{SD}$ \\
$\mathbf{2 0 1 4}$ Study & $77.86 \mathrm{BP}$ & $43.31 \mathrm{BP}$ & $0.00 \mathrm{BP}$ & $316.18 \mathrm{BP}$ \\
& & $-1.80 \mathrm{SD}$ & $+5.50 \mathrm{SD}$ \\
\hline
\end{tabular}

In a level 1 market where an observable fair value quote exists, it is not an accumulation of different observable quotes with a distribution about a mean and a small standard deviation; it is a distribution about a mean with a standard deviation of zero, a singularity. Since no market exists for level 3 assets and liabilities, the values recorded for a particular asset or liability across all firms that hold that asset or liability would provide for a distribution with a mean that may act as a proxy for the market consensus of fair value. To the extent that the related standard deviation is small or immaterial in relation to the mean one may argue that a market-based measure of fair value is the mean and an accurate measure of fair value. As the standard deviation increases, there comes a point where that conclusion is no longer valid. The problem here is at what point does the standard deviation cross the line from a market-based fair value to a firm-specific value (which, by definition, is not fair value)? There is no guidance to answer that question. But it is a moot point, as there is no mechanism to measure each different level 3 asset and liability to know what their distribution characteristics are. To that end, a market-based fair value measurement cannot be achieved. 
Because the 2004 study was supportive of PAT, the authors were able to reject the null hypothesis that managers were not exercising discretion. While the 2014 study was not supportive of PAT but the fair value distribution is the same as the 2004 study strongly suggests that discretion was still being exercised but for different reasons.

Consider the example of JPMorgan Chase \& Co. In 2010, the last year of the second study, they reported \$13.6 billion of MSRs related to a servicing portfolio of $\$ 976$ billion, or $139 \mathrm{BP}$. Their level of capitalization is $61 \mathrm{BPs}$ or 1.4 standard deviations higher than the population as a whole. This translates to an excess value of $\$ 6$ billion. If one takes the position that the standard deviation in the second study does not cross the line from a market-based fair value to a firm-specific value, then $77.86 \mathrm{BP}$ is the market consensus for the fair value of MSRs. In that case, JPMorgan has overstated the fair value of their MSRs by $61 \mathrm{BP}$, or $\$ 6$ billion dollars. Therefore, a market-based fair value measure has not been achieved with respect to them. If one takes the position that the standard deviation in the second study does cross the line from a market-based fair value to a firm-specific value, then there is no market consensus and all values across firms are firm-specific values.

One might anticipate the argument that servicing portfolios are sufficiently heterogeneous as to allow for the range of values and standard deviations reported in the two studies. This argument implies that some firms may have the ability to originate mortgage loans that produce MSRs that are of a higher quality than can other firms. JPMorgan cannot make this claim (nor can any financial institution insured or regulated by a federal agency). JPMorgan has an obligation to "serve" their entire market. To do otherwise would be to engage in some degree of "redlining" which was banned in 1968 by the Fair Housing Act. The mortgage origination market is highly competitive and it is reasonable to assume that all originators are participating in the market as a whole and, therefore, originating a representative sample of loans and MSRs.

Additionally, as of September 2015, 61.1\% of all outstanding U. S. mortgage loans were owned by the Federal National Mortgage Association (Fannie Mae), Federal Home Loan Mortgage Corporation (Freddie Mac) and the Government National Mortgage Association (Ginnie Mae) (Valuewalk, 2016). These loans are originated, underwritten and serviced according to exacting standards that all originator/servicers must follow. They are the epitome of homogeneity.

There is no reason to think that the managers at JPMorgan do not exercise the same discretion with respect to their MSRs as does the industry as a whole. The evidence more than supports the idea that they do. If that discretion is exercised with respect to MSRs, there is no reason to think that the same discretion is not exercised with respect to all their level 3 assets and liabilities. Their 2016 balance sheet (through the notes to the financial statements) report $\$ 23.2$ billion of level 3 assets and $\$ 25.4$ billion of level 3 liabilities.

Finally, it should be noted that the distributions provided by both studies are not normal. They are skewed significantly to the right. The propensity for managers to overvalue MSRs is much greater than to undervalue them. This is troubling for obvious reasons.

\section{Concluding Remarks}

This paper puts forth the argument that a market-based fair value measurement may not be achieved for level 3 assets and liabilities. Data from two studies that examined the measurement of MSRs, a level 3 asset, is compared pre- and post-SFAS No. 157. The results of the 2004 study provided evidence that managers of financial institutions do exercise discretion when capitalizing MSRs. Since the distribution of the 2004 study resulted from management discretion, and since the 2014 distribution is the same and the market participants are essentially the same, it is reasonable to conclude that discretion is still being exercised. The exercise of discretion belies the notion that MSRs are being recorded at fair value as envisioned by ASC 820.

The evidence supports the notion that managers are exercising discretion with respect to the recording of MSRs. Whether this conclusion is generalizable to all level 3 assets and liabilities is unknown as similar studies of other fair value assets and liabilities have not been conducted. Given the significant empirical support that PAT has received since its introduction in 1978, one can think of no argument that would support the notion that managers across all firms with level 3 assets and liabilities would not act as do managers who value MSRs.

The findings in this paper should be troubling to everyone, especially the FASB. Level 3 assets and liabilities are embroiled in a greater degree of complexity than other assets and liabilities. Coupling that complexity with the ability of management to influence the valuations sets the stage for discretionary behavior. More scrutiny of these assets is needed. If it is learned that a relevant and reliable measure of these assets and liabilities are not being recorded, there needs to be a re-thinking of how they should be measured, recognized and recorded. 


\section{References}

Alali, F. \& Anandarajan, A. (2015). The interaction between LLP and SFAS 157 and its role in the choice of tools for earnings and capital management by banks during a financial crisis. Quarterly Journal of Finance and Accounting, 53(1/2), 1-31, 33-42.

Cochran, R., Coffman, E. \& Harless, D. (2004). Fair value capitalization of mortgage loan servicing rights. Research In Accounting Regulation, 17, 153-164. http://dx.doi.org/10.1016/S1052-0457(04)17007-0

Cochran, R. J. \& Shelnutt, H. (2014). An examination of mortgage loan servicing rights in the aftermath of the subprime mortgage crisis of 2006. Accounting and Finance Research, 3(1), 46-53. https://doi.org/10.5430/afr.v3n1p46

Magnan, M., Menini, A. \& Parbonetti, A. (2015). Fair value accounting: Information or confusion for financial markets?. Review of Accounting Studies, 29(1), 559-591. https://doi.org/10.1007/s11142-014-9306-7

Song, C. \& Thomas, W. B. (2010). Value relevance of FAS No. 157 fair value hierarchy information and the impact of corporate governance mechanisms. The Accounting Review, 85(4), 1375-1410. https://doi.org/10.2308/accr.2010.85.4.1375

Tan, P. (2015). Fair value hierarchy: Post-implementation evidence on IFRS 7. GSTF Business Review, 4(1), 105-113, 235-80. https://doi.org/10.7603/s40706-015-0013-6

Valuewalk. (2016). Fannie Mae: Who owns the U.S. Mortgage Markets? http://www.valuewalk.com/2016/03/fannie-mae-who-owns-the-u-s-mortgage-markets/

Watts, R L. \& Zimmerman, J. L. (1978). Towards a positive theory of the determinants of accounting standards. The Accounting Review, 53(1), 112-134. 